\title{
A PROCESS OF CHANGE AND A CHANGING PROCESS: INTRODUCTION TO THE SPECIAL ISSUE ON CONTEMPORARY GENTRIFICATION
}

\author{
BRIAN DOUCET \\ Utrecht University, Urban and Regional Research Centre Utrecht (URU), PO Box 80.115, 3508 TC, \\ Utrecht, the Netherlands.E-mail: b.m.doucet@uu.nl
}

Received: January 2013; accepted November 2013

\begin{abstract}
Gentrification is a process of social and spatial change, but it is also a changing process. This special issue aims to better understand new forms of gentrification, policies and experiences which have emerged since the year 2000. Specific emphasis has been given to the Netherlands, a country where the strong role of the state and more than two decades of pro-gentrification policy have created a unique context where gentrification is pursued, implemented and experienced in different ways than in the Anglo-Saxon world. Research into Dutch gentrification has led to new theoretical insights in the past and the papers in this special issue should present international readers with new and alternative perspectives towards contemporary gentrification, thereby contributing to a wider understanding of the 'geography of gentrification'. This introduction will examine new spatial and social manifestations of gentrification over the past decade, examine what binds them together as part of the gentrification process, introduce Dutch gentrification and outline the papers featured in this special issue.
\end{abstract}

Key words: Gentrification, special issue, social class, the Netherlands, Amsterdam, urban policy

\section{INTRODUCTION}

Gentrification is one of the biggest forces shaping contemporary cities. It has been labelled a 'dirty word', (Smith 1996) and the most politically-loaded word in urban geography (Davidson \& Lees 2005). The process was originally coined by sociologist Ruth Glass (1964) to describe the upgrading of old working-class housing in inner-city London. What now constitutes gentrification has evolved over the past 50 years to include many different spatial forms involving different groups of people. Since Jan van Weesep's (1994) call to put gentrification into a policy perspective, it has been viewed much more as an urban strategy (Smith 2002) rather than just the practices of a small group of middle-class professionals. All of these changes have combined to push the definition of the term towards a broader concept of an upward class transformation and the creation of affluent space (see Smith 1996; Clark 2005; Slater 2006).

This special issue will examine new forms, policies and experiences of gentrification which have emerged over the past decade, with an emphasis on the Netherlands. The empirical studies will focus on a variety of groups and themes: gentrifiers, those under threat of displacement, those 'living through' the process and the role of urban policy. The unique characteristics of the Netherlands, with its strong role for the state (van Weesep and Wiegersma 1991; Aalbers 2011; Doucet et al. 2011) and 
long history of pursuing gentrification as an urban policy (Musterd and van der Ven 1991; van Kempen and van Weesep 1994; Uitermark et al. 2007; Uitermark 2009; van Gent 2013), and generally more mild forms of gentrification than in the Anglo-Saxon world, help to contribute to a wider theoretical and empirical understanding of the 'geography of gentrification' (Lees 2000, 2012).

This introduction is divided into four parts. First, it will examine different spatial and social manifestations of gentrification, particularly those which have emerged over the past decade. Many, such as family gentrifiers, or commercial gentrification, will be further examined in specific articles in this issue. Second, it will examine why gentrification is still a useful and relevant concept despite the fact that what constitutes contemporary gentrification now encompasses so many different forms and groups of people. It will focus on what binds these different forms of gentrification together and why choosing to use the term gentrification, rather than using other terms such as 'social mixing' or 'reurbanisation', precludes authors and commentators from acknowledging the inherent inequalities which are central to the process. Third, the paper will give an introduction to Dutch gentrification and, finally, it will introduce each of the articles featured in this special issue.

\section{KEY ISSUES IN CONTEMPORARY GENTRIFICATION}

Hackworth and Smith's (2001) assessment of the progression and spread of gentrification remains one of the leading analyses on the stepwise development of the process. Dividing their analysis into three distinct waves or phases, they argue that each one was punctured by a major recession. The third phase, which began after the recession of the early 1990s, has four characteristics: it was primarily developer, rather than household-led, the role of governments was strengthened, anti-gentrification movements became more marginalised and it was spreading to neighbourhoods outside the city centre. They analysed and introduced many new types of gentrification that had arisen or blossomed during the 1990s, citing examples of luxury new-build condominiums in Long
Island City, Queens, developer-led loft conversions in DUMBO, Brooklyn and the removal of municipal policies aimed at preventing gentrification and displacement in the Manhattan neighbourhood of Clinton. In the years since this article was published, new spatial forms of gentrification have emerged. The next subsection examines some of the most influential literature on new forms of gentrification over the past decade.

Spatial manifestations of contemporary gentrification - As Neil Smith (1996, p. 39) has observed: 'Gentrification is no longer about a narrow and quixotic oddity in the housing market but has become the leading residential edge of a much larger endeavour; the class remake of the central urban landscape'. The spatial and physical manifestations of the term have evolved as urban development has changed. A major form of contemporary gentrification is the transformation of old industrial brownfield sites into high-end, new-build developments (Davidson \& Lees 2005). Newbuild gentrification was first examined in British cities, however it is now common in other countries in both the Global North and Global South. The construction of mixed-use 'flagships' on old industrial lands - waterfronts were a particularly popular location - was a hallmark of 1980 s and 1990s urban entrepreneurialism. In the decade leading up to the Great Recession, the trend was more towards mono-use housing, rather than a mix of offices, shops, leisure facilities or tourist attractions. In cities such as Glasgow, housing developments replaced convention centres and tourist attractions as the primary drivers of waterfront (and other brownfield) regeneration (Doucet 2013). While not initially considered gentrification by all scholars (Boddy 2007; Buzar et al. 2007), most academics now see this landscape as part of the evolving nature of contemporary gentrification. Davidson and Lees outlined four reasons why newbuild developments should be considered part of the gentrification process: reinvestment of capital; social upgrading; landscape changes; and displacement.

A second new form of urban redevelopment which has come to be seen as part of the gentrification process is the restructuring of 
housing estates, either on the periphery of cities (Uitermark et al. 2007; Glynn 2012) or in more central areas (August \& Walks 2012). Again, this fits in with the framework of thirdwave gentrification, with a strong role for the state, and often taking place in more peripheral geographic locations. In this instance, gentrification - creating affluent housing in a low-income neighbourhood - is used as a (sometimes explicit) policy tool to create a social mix in what were largely low-income, social housing neighbourhoods (see Bridge et al. 2012). Uitermark et al.'s (2007) article on the restructuring of the post-war neighbourhood of Hoogvliet, Rotterdam represents one of the major theoretical understandings of the workings of gentrification to emerge over the past decade. They asserted that this new form of gentrification was being used as a way of creating social order, pacifying the population and reducing tensions between residents. This claim fits broadly within Smith's (1996) revanchist idea. But it also offered an alternative explanation to the goals of gentrification, which were assumed to be more about urban entrepreneurial strategies, enhancing quality of life or taking back the city from the poor.

Third wave gentrification has also moved beyond the city. Martin Phillips contests that rural gentrification should also be seen as part of the process. While the term 'rural gentrification' is not new (see Phillips 1993), it is becoming increasingly linked to its urban counterpart (see Smith and Phillips 2001; Darling 2005). Phillips (2004) seeks to contribute to our understanding of the 'geography of gentrification' and takes issue with the urban focus of the debate by its leading scholars. While in earlier work, he argued that there are distinct differences in the desires and preferences of middleclass gentrifiers in the city and middle-class households moving to rural locations (see Phillips 1993; Smith and Phillips 2001), his later work seeks to find parallels between these two spatial realms.

While primarily a housing-oriented phenomenon, gentrification research has begun to focus on other aspects of neighbourhood and class transformation. Commercial gentrification is a small, yet growing, area of research which seeks to capture the fact that when a neighbourhood becomes gentrified, it is not just the housing landscape which changes. Slater (2006, p. 738) remarked that:

The perception is no longer about rent increases, landlord harassment and workingclass displacement, but rather street-level spectacles, trendy bars and cafes, i-Pods, social diversity and funky clothing outlets.

Scholars such as Zukin (2008) and Bridge and Dowling (2001) argue that commercial gentrification represents the lifestyle and values of its users. Zukin (2009), for example, characterises the process as 'boutiquing', and Bridge makes the link between commercial gentrification and the concept of Bourdieu's 'habitus' (Bridge 2006, 2001). While some studies focus on the search for authenticity among gentrifiers (Osman 2011), others have emphasised the tensions and conflicts inherent with this class transformation of the retail landscape; Cheshire (2012) notes that non-gentrifying residents have little need for these new amenities, nor can they afford to pay for them. And Deener (2007) highlights the tensions present in Venice Beach, California between the incoming gentrifiers who claim authenticity over the commercial space, at the exclusion of the area's poor, African-American population. In this special issue, Ernst and Doucet (2014) will examine to what extent pubs and cafés reinforce or reduce tensions between gentrifiers and nongentrifiers and Karsten (2014) will examine the commercial spaces of family gentrifiers.

Partially linked to commercial gentrification, tourism gentrification (Gotham 2005) focuses on how the promotion of tourist spaces can lead to gentrification. As Gotham demonstrated with his study on the Vieux Carré in New Orleans, multinational entertainment and commercial firms tap into global circuits of capital to invest in local residential and commercial spaces. He argues that rather than capital reacting to the demands of consumers themselves, 'consumer taste for gentrified spaces is, instead, created and marketed, and depends on the alternatives offered by the powerful capitalists who are primarily interested in producing the built environment from which they can extract the highest profit' (Gotham 2005, p. 1114).

Since 2000, much-needed attention has been paid towards gentrification in non-Western 
contexts. Atkinson and Bridges' (2005) edited book 'Gentrification in a global context' was the first to dedicate a significant share of its chapters to case studies beyond the West. Scholars working in both the Global North and the Global South have turned their attention towards new forms of gentrification emerging in many different countries, such as China (He 2010), South Africa (Visser and Kotze 2008) and Turkey (Islam 2005), among others. Cities in the Global South are experiencing "mega-gentrification" and associated "megadisplacement"' (Lees 2012, p. 164) on a scale not seen in Europe and North America. Bahar Sakizlioglu (2014, this issue) will examine this in greater detail with her study of displacement in Istanbul.

As gentrification progressed during the 1990 s and early 2000s, Lees et al. (2008) argued that there was a fourth wave of gentrification, which began around 2002. Two elements distinguish the fourth wave from the third wave: the financialisation of housing and a consolidation of the pro-gentrification policies which dominated the third wave. New policies, which both favour the most affluent households and dismantle social welfare programmes, have created the context for this new phase of gentrification. The authors argue that the fourth wave is a distinctly American phenomenon, and make further calls for a greater understanding of the geography of gentrification. Though, as van Gent (2013) notes, the third wave has not yet fully broken in Western Europe, and it still remains the dominant form of gentrification in many countries there. The fourth wave of gentrification has received less attention than Hackworth and Smith's three wave model. This is partly because the fourth wave is seen as more of an extension or modification of existing policies, rather than as a bold departure from existing urban forms and spatial locations (as between the second and third waves). When Lees et al. published their work on the fourth wave of gentrification in 2008, the world was also on the cusp of the current economic crisis, which has, in many cities, slowed or stopped gentrification, particularly in new-build developments and in more marginal cities and neighbourhoods. While this is not an exhaustive list of the new forms of gentrification, it clearly shows that the what, where and why of gentrification have evolved considerably since the year 2000 .

The gentrifiers, the displaced and those inbetween' - Just as what constitutes gentrification has evolved, who experiences it, and more importantly, our understanding of those experiences, has also progressed. Since 2000, much attention has been given to the gentrifiers, yet pioneering work on these groups was begun by David Ley, among others, in the 1980s. Through statistical analysis of major Canadian cities, he noted that those upgrading inner-city neighbourhoods in the 1970s were employed in quaternary categories including administrative, professional, managerial and technical occupations (Ley 1988). His early work also showed that these residents cited different factors concerning their preference for gentrified areas, including proximity to work and downtown, environmental amenities, neighbourhood characteristics, historical status, affordability and investment potentials (Ley 1988). As Lees et al. (2008) note, Ley's work has always been about 'peopling' human geography. Ley's work was also heavily influenced by Bell's (1973) post-industrial thesis, which focused on the shift from manufacturing to services, the role of science-based industries, a growth in managerial, professional and technical occupations and artistic-led consumer culture (see also Lees et al. 2008).

Another early work examining the gentrifiers was by another Canadian, Jon Caulfield (1994), in his book City, Form and Everyday Life. In it, he argued that the inner-city became an emancipatory space, free from the conformity of the suburbs. Caulfield's emancipatory city theory fell under criticism from scholars such as Lees (2000, p. 393), who stated: 'his thesis obscures the fact that anti-gentrification groups, often composed of working-class and/or ethnic minorities do not always share the same desires as gentrifiers'.

Building on early work such as this, and David Ley's (1996) book The New Middle Class, research over the past 10 to 15 years has focused on a variety of topics surrounding gentrifiers: who the gentrifiers are, why they settle in the inner-city, how gentrification represents their tastes and values, their daily-life practices, how they mix (or do not mix) with non-gentrifiers 
(Butler 2003) and their housing careers and expectations, among other topics. Bourdieu's notion of cultural capital has been employed to argue that gentrified spaces become representations of the cultural and aesthetic values of the new-middle class (Bridge 2001, 2006) or, in the case of Ley's (2003) study, of artists. In Ley's view, the artists provided the necessary cultural capital to pave the way for gentrifiers and middle-class commercial consumption.

Until recently, much of the literature on the gentrifiers assumed that they were at a particular stage of their lives, which began as they entered the professional working world and ended upon starting a family, when many moved to the suburbs. They were young, single and childless and worked in professional occupations (Caulfield 1994; Ley 1996). Demographics have often been shown to play a role in housing choices (Rossi 1980); practices such as delaying marriage or starting a family created a window in which one could live in and enjoy the city. This is vividly explained in the book Through the Children's Gate by Adam Gopnik (2006) which describes his experiences raising a family in post-9-11 New York City. He describes a conversation he had with a real estate developer who explained to the author that:

you can ask a thirty-year old with children to move to New Jersey, but you can't ask a single thirty-year old to move out there before he or she has found a mate. He or she would basically rather die ... That's the great secret, the key demographic of New York. Kids at twenty-five, cities die; kids at thirty five, cities thrive. It's just that simple (Gopnik 2006, p. 147).

This ten year period was initially thought to be the primary life-course stage for gentrifiers. However, the last decade has seen the notion of the gentrifier challenged at both ends of age and life-course spectrum.

Gopnik represents part of a new type of gentrifier which has emerged over the past decade: middle-class families raising children in the city. Lia Karsten's work has examined people such as Gopnik, and introduced the term 'yupps' - young urban professional parents - in 2003 to distinguish the difference in life-course between the family gentrifiers and the more traditional 'yuppies'. Gentrified spaces were important for balancing the different demands of middle-class parents, including building a career, caring for children, and keeping culturally and socially active. Living in the inner-city "united [the] combination of careerism and familism' (Karsten 2003, p. 2582). Schools are an important mechanism for social reproduction among family gentrifiers; Willem Boterman's (2013) study examined different strategies by middle-class parents to find, or even create, the right kind of innercity schools.

At the younger end of the spectrum, Darren $\mathrm{P}$ Smith's (2005) work illustrates how students fit into the gentrification process through his pioneering work on studentification. Studentification spaces become factories of gentrification, where apprentice gentrifiers could acquire their cultural capital. He argues that studentification is also part of gentrification because of the increased social and spatial polarisation it brings through displacement of existing residents. There is economic investment in property, though, contrary to other forms of gentrification, it often comes coupled with a physical downgrading of the built environment. Together with Smith and Louise Holt (2007), they examined the role of students in gentrification in provincial cities. They sought to examine how gentrification fits into wider lifecourse cycles and, in relation to students, argue 'that the narrow temporal view of gentrifiers obfuscates how the 'experiences' of young people and studenthood may be implicated within the (later) cultural and residential inclinations of gentrifiers' (Smith and Holt 2007, p 144).

The other area where the definition of the gentrifiers has been expanded is at the very high-end of the spectrum. Early gentrifiers were professional, middle-class households, often employed in education, architecture or the civil service. More recently, the concept of the gentrifier has been expanded to include the super-rich. Lees (2003a) and Butler and Lees (2006) developed the term 'supergentrification' to describe the process, which they observed in the global cities of London and New York, whereby previously gentrified areas see a further upward class transformation by a new group of super wealthy 
professionals. In his afterword, Gary Bridge (2014) will reflect on the increasingly diverging trajectories of today's middle classes.

The focus on the gentrifiers was one of the reasons why Tom Slater (2006) stated that the critical perspective had itself been 'evicted' from gentrification research. His call to bring back critical scholarship into the debate has been answered by many academics; Wacquant (2008) and Watt (2008) also argued for more emphasis on the working-class and 'bottom up' perspectives. Conducting research in Scottish cities, both Kirteen Paton and Sarah Glynn have provided empirical responses to Slater's call by analysing the experiences of those who are under threat of being displaced. Paton (2012) examines Partick in Glasgow. She questions the idea that middle-class-driven gentrification can be the saviour of the city because 'it offers a cultural solution to fix economic and structural issues of poverty, unemployment and the decline of the built environment' (Paton 2012, p. 255). Her empirical research is based on in-depth ethnographic work exploring the everyday lives of working-class residents. Glynn (2008, 2012) focused on the demolition and conversion of high-rise social housing blocks in Dundee, concluding that the needs of the existing tenants were often ignored and that democratic process is being undermined in pursuit of neoliberal, urban entrepreneurial practices. In a similar vein, Carla Huisman (2014, this issue) will examine ways in which residents do, and do not participate in tenure conversion of social-rented housing. Bahar Sakizlioglu (2014, this issue) will analyse the experiences of living under threat of displacement in Istanbul.

Finally, a small, yet growing body of research has examined those who are neither the gentrifiers, nor the displaced. The concept of 'living through' gentrification is gaining more attention and empirical work has examined the experiences, perceptions, challenges and opportunities for those who are not displaced as their neighbourhood becomes middle-class. Freeman (2006) was one of the first scholars to examine this topic through a study of two neighbourhoods in New York. He found that the presence of social housing could help keep residents in the neighbourhood. Many residents welcomed certain aspects of gentrifica- tion, such as better policing and more amenities, yet there were conflicts over habits and practices on streets and in public space. In many of these studies, the links with commercial gentrification are strong. Sullivan and Shaw (2011) found distinct racial divisions between long-term African American residents and long-term white residents in their appreciation of commercial gentrification in Portland, Oregon, with the former being much more negative than the latter. Doucet's (2009, p. 312) work on Leith, Edinburgh found that while many residents living through gentrification welcomed the new amenities and image of the neighbourhood that it brought, there was a strong 'not for us' sentiment; 'they were positive about the changes in the neighbourhood, though more pessimistic about the changes in their neighbourhood'. Among the papers in this special issue, Ernst and Doucet will examine the experiences of living through gentrification in Amsterdam and how these are made manifest in commercial spaces.

Gentrification as an urban policy - In addition to the growing interest in the gentrifiers, the past decade has seen a strong international emphasis on examining gentrification as an urban policy. As will be outlined in more detail in the section on Dutch gentrification, geographers from the Netherlands have been at the forefront of this research for well over 20 years (Musterd and van der Ven 1991; van Kempen and van Weesep 1994). Hackworth and Smith (2001) made the role of public policy one of the focal points of their third wave of gentrification, and, a year later, Neil Smith (2002), in an article which has become one of the most cited in gentrification studies, declared that gentrification was a global urban strategy. The intervening years have clearly demonstrated the centrality of gentrification as an urban strategy and many articles (and even a special issue - see Lees \& Ley 2008) have been devoted to exploring this relationship. In their introduction, Lees and Ley note that gentrification has changed from being seen as a problem for policy-makers, to being seen as a solution. The concept is underscored by the ways in which gentrification is more openly promoted in urban policy. In old, industrial cities, such as Rotterdam, gentrification is a deliberate and 
overt strategy (Doucet et al. 2011). The municipality's own Urban Vision states:

these districts [neighbourhoods adjacent to the city centre] are increasingly popular among (former) students and those active in creative industries; these are exactly the groups Rotterdam wants to attract. In social, cultural and economic terms, these districts have the features necessary for an autonomous gentrification process ... The municipal authorities support this process with appropriate measures (Rotterdam 2007, p. 70$){ }^{1}$

In the UK, Lees (2000) has noted that the divisions between gentrification and urban regeneration have become blurred.

One of the newest strands of research examines the role gentrification plays in urban restructuring and policies of social mixing. The term 'social mixing' is a much less negative one than 'gentrification'. As such, it is favoured by policy-makers and is used by many scholars who take a less critical, or class-based view of the process (see Posthumus 2013). A major advance in this link between the two terms was made through the publication of Bridge et al.'s (2012) edited book Gentrification by Stealth. This book was an excellent attempt to bridge the divides between literature on social mixing, which is less critical and more widely used by policy-makers, and on gentrification, which they argue has been 'rhetorically and discursively disguised as social mixing' (Bridge et al. 2012, p. 1). In itself, social mixing implies much less of a class-based tone; perhaps because it has fewer negative connotations and political baggage, it has been adopted as the preferred term by policy-makers. Working within similar frameworks, UK scholars, such as Loretta Lees, have examined policies of the former Labour government aimed at using new forms of gentrification to create some degree of social mix in low-income housing estates in British cities (Imrie \& Raco 2003; Lees 2003b).

\section{WHAT UNIFIES GENTRIFICATION RESEARCH?}

There are so many perspectives on contemporary gentrification that what is now included as part of the term has been stretched to the point where some have questioned its analytical use (Boddy 2007). While not the first time this question has been posed, after an examination of the new strands of gentrification research which have emerged over the past decade, it does beg the question as to what unifies gentrification research?

To understand what binds these different forms of gentrification together, we should return to Ruth Glass's initial observations and definition of the term:

One by one many of the working class quarters of London have been invaded by the middle class . . have been taken over when their leases expired, and have become elegant, expensive residences ... once this process of 'gentrification' starts in a district it goes on rapidly until all or most of the working class occupiers are displaced and the whole social character of the district is changed. (Glass 1964, pp. xviii-xix)

Up until the 1990s, scholars considered gentrification to be a process involving middle-class (white) professionals, older housing stock and inner-city neighbourhoods akin to the spatial description given by Glass. New forms of gentrification, which have emerged since then continue to challenge this view. While Glass was describing a particular place at a specific moment in time (inner-city London in the 1960s), she was, more importantly, describing a social process: the upward class transformation of a neighbourhood and the displacement of its low-income population. With this in mind, these new forms of gentrification do hold true to its initial definition, even though the spatial locations, physical forms and actors involved have all changed. Gentrification research is a continually changing endeavour, which evolves as new spatial forms develop; but it is the process of change - class change - that has remained a constant focus since Glass' day. As Clark (2005, p. 258) succinctly stated: 'It does not matter where, and it does not matter when. Any process of change fitting this description is, to my understanding, gentrification'.

With so much emphasis on promoting gentrification within policy circles, academic attention, more than ever, needs to focus on the class-transformations brought about by gentrification more than ever. As some scholars have 
noted, the working-class do not feature prominently in wider discussions (Slater 2006; Wacquant 2008; Watt 2008). Lees (2003b, p. 71) wrote that the UK government's 'urban policy assumes we are all middle class'. Positive policy discourse focuses on middle-class tastes and values, better amenities, rising property values and urban revitalisation, ignoring tougher social issues such as displacement and housing affordability (Lees 2003b). What gentrification scholarship does is to remind us that behind this middle-class ideal, which is so highly sought after, there are many others who are excluded.

Examining the habits and preferences of the gentrifiers themselves is an important part of the overall understanding of this class transformation. But even studies which do not specifically examine the negative consequences of gentrification must, by choosing to use the term gentrification as the primary way of framing research, acknowledge the inherent inequalities within the process. Authors who use less politically-loaded words are much more free to focus solely on the benefits of the process. In this special issue, Karsten's (2014) study of middleclass family consumption spaces explicitly uses the term gentrification, and while she examines the practices of gentrifiers, she, too, ends on a critical note by stating that the progression of gentrification will lead to a further 'spacialisation of class'. Gentrification studies is a field where middle-class rhetoric and the values, experiences and habits of those living such a lifestyle, meet the working-class and lowincome reality that so many others struggle through. Gentrification remains one of the most vivid urban arenas in which issues of class are played out in distinct social and spatial ways.

Not all of the papers in this special issue explicitly use class as their unit of analysis; Boterman and van Gent (2014) make a case for examining demographic and ethnic factors in addition to class, and Karsten (2014) uses sociodemographic change as the starting point for her paper. But framing these two processes tenure conversion and consumption spaces for families living in the city, respectively - under the context of gentrification remains the most useful analytical term.

Despite its many guises, gentrification remains a relevant term more than 50 years after it was first coined. It remains so because it captures the different interpretations and experiences of this process of neighbourhood change better than any other word. Many associate gentrification with hip bars and cafes, trendy shops and restored middle-class homes (see Slater 2006). Gentrification accurately captures the desires, experiences and challenges of middle-class households, whether they be singles, families, students or otherwise, who wish to live, play and consume in the city. The dream for many of living in a restored Victorian house and frequenting the hip neighbourhood shops and cafés of the inner-city represents the pinnacle of an urban idyll which is encapsulated through the word 'gentrification' far better than by any other term. For many others, however, gentrification evokes feelings of conflict, tensions and displacement. Despite its association with middle-class urban dreams, gentrification can also describe the painful displacement of families and communities far more brutally than a term such as 'reurbanisation', 'resilient cities', or 'social mixing' ever could. It vividly captures all sides to this process which is continuing to reshape urban (and increasingly non-urban) spaces around the world. It is a reminder that you do not have to scratch far beneath the surface of the glamour of luxury waterfront residences, new owner-occupied housing in peripheral estates or the latest trendy café to find exclusion, polarisation and inequality caused by the very policies and processes celebrated for their ability to 'revive' cities.

\section{DUTCH GENTRIFICATION}

While gentrification remains, as Davidson and Lees (2005) pointed out, the most 'politically loaded' word in human geography, we should not assume that it has the same meaning, practice or experience in different places. This section will introduce Dutch gentrification, which has many unique qualities that challenge many of the key assumptions about the process, especially as seen from an Anglo-Saxon perspective. Like elsewhere, we can see different forms of gentrification, but compared to other mainland European countries, the process took hold and was documented much earlier. (van Weesep \& Wiegersma 1991). 
A major factor which makes Dutch gentrification stand out is the role of urban policy. Gentrification has been central to Dutch housing policy (both at the national and local levels) for more than two decades. Jan van Weesep's 1994 call for gentrification to be examined through a policy perspective was borne out of this context in the late 1980s and early 1990s. Together with Ronald van Kempen, he examined gentrification and housing policy in Utrecht (van Kempen \& van Weesep 1994). They noted that after decades of expanding the welfare state, partly done through the building of affordable housing, Dutch housing policy changed in the early 1990s towards the promotion of more expensive dwellings. While one of the major reasons for this was budgetary, and the need to reduce the state's housing expenses, another key reason was due to the small proportion of expensive, high-end dwellings which existed in cities at that time. Due to the growth of regional housing markets, suburban development and planned growth centres (new towns), many middle-class households suburbanised and urban populations dropped. There was a fear among policy-makers that middle and higherincome households would continue to move to the suburbs because of the lack of appropriate housing for them within cities.

Musterd and van der Ven (1991) took a different approach to explain early Dutch policies towards promoting gentrification in the late 1980s. At this time, Dutch cities (Amsterdam in particular) were suffering from a mismatch of jobs - which were located in the city - and middle-class residents - who were living in the suburbs. Central to this policy was the hope that more of the money earned in Amsterdam would also be spent there by a growing number of more affluent residents. Urban policy shifted away from the provision of social housing and urban renewal, which had dominated national and local housing policies since the Second World War, towards new housing for higherincome groups. As they noted as far back as 1991: 'Gentrification was embraced as the lifebuoy for the big city' (Musterd \& van der Ven 1991, p. 92). While van Weesep and Wiegersma (1991, pp. 98, 108) examined the role of the private-sector in stimulating gentrification, they too concluded that the practices of devel- opers are 'contingent upon the rules set by the public sector' which 'defines the conditions for the entire process'.

Central to Dutch housing policy over the past few decades has been a movement away from the promotion and construction of social housing (though it still represents a larger share of the overall housing stock than found in most European countries). The effects of this transition have been very rapid (van Gent 2013). Justus Uitermark (2009) demonstrated how, in the 1980s, Amsterdam had almost achieved its policy goal of being a socially just city, with waiting times for social housing reduced to only a few years. Yet, by the 1990s, the city had largely abandoned this goal in favour of market-driven solutions to housing and waiting times rose dramatically again.

In addition to the central role of policy in shaping gentrification, there are many other unique factors in Dutch gentrification, most notably the comparatively strong role for central and local governments, and the role of housing associations, which remain important players in urban housing markets (see Teernstra \& van Gent 2012). As several papers in this special issue will illustrate, the role of housing associations as a primary stimulator of gentrification is growing (see Boterman \& van Gent 2014; Huisman 2014). Gentrification has always been more regulated and managed in Dutch cities. Therefore, the interventionist and managed-nature of Dutch gentrification offers insightful comparisons with other countries, particularly Anglo-Saxon examples, where laissez-faire approaches to housing are more common. Van Kempen and van Weesep's 1994 reflection on the unique nature of the Netherlands is still salient and a useful source for international comparison today:

extensive housing market regulations interfere with market logic. Regulations, direct action and subsidies have so far provided low-income households with access to goodquality dwellings. The provision of a large, non-stigmatised social housing stock has prevented the emergence of socially segregated areas, slums and ghettos. Many middle-income households continue to live in social housing. But at the same time, low- 
income households can move into affordable rental housing that is sprinkled throughout attractive neighbourhoods. Housing market controls and urban renewal policies have prevented even the most presitigous residential areas from becoming homogeneously high-income districts (Kempen \& van Weesep 1994, p. 1054).

While many of these points have been challenged by two decades of neoliberal urban policies, when seen through an international context, they are still strengths of the Dutch housing system, and make it stand out in Europe and beyond.

In the Netherlands, new forms of state-led or top-down gentrification continue to emerge which are rooted in its specific politicaleconomic and temporal contexts. The latest form of gentrification is tenure conversion where housing associations sell off dwellings, which then take on different forms of tenure (not necessarily always owner-occupied) (Boterman \& van Gent 2014, this issue; Huisman 2014, this issue). While in some ways similar to the right-to-buy initiative of the UK, there are several notable differences, which will be explored by these two papers in more detail.

A major conclusion from most studies of Dutch gentrification is that more attention needs to be paid to what Lees $(2000,2012)$ has referred to as a 'geography of gentrification', that is the context and the temporality of gentrification. The role of local policies, practices, institutions and actors matters in determining the goals of gentrification and its impact. Gentrification as an urban policy dates back to the 1980s (van Kempen \& van Weesep 1994) and the term is used far more explicitly by policymakers than in other countries (Doucet et al. 2011). Uitermark et al., (2007, p. 127) uncovered an entirely new discourse on the reasons behind state-led gentrification: the process was intended to 'lure the middle classes into disadvantaged areas with the purpose of civilising and controlling these neighbourhoods'. Others, such as Aalbers (2011) have argued that less aggressive forms of revanchist policies can be found in Dutch cities. In his study of the Bijlmer regeneration, he found a combination of hard and soft policies, which were aimed at improving the quality of life of both lower and middle income residents. Aalbers (2011, p. 1719) stated that:

[t] his does not imply that the Netherlands, like the USA, has moved from neglect towards punitive measures - Amsterdam may have incorporated some elements of the revanchist city but it is not a 'post-justice city'. This brings us to the idea of a 'geography of revanchism'.

The work of Aalbers, as well as Fainstein's (2008) comparison of megaprojects in New York, London and Amsterdam, both point to less extreme, or milder forms of gentrification in the Netherlands, because of its comparatively strong welfare state and interventionist policies.

For a deeper understanding of the geography of gentrification, it is imperative to examine the process in different parts of the world. However, while gentrification can be found almost everywhere, most (though not all) of the key theorists still live, work and conduct their research in an Anglo-Saxon context. Many of them work on either New York or London, places which have preeminent world city status (GaWC 2010). Their positions as the two centres of global finance lead to very different political, economic, demographic and social realities compared to both other cities in their respective countries, and other parts of the world (Friedmann 1986). Dutch gentrification offers a counter perspective to the laissez-faire capitalism and comparatively unregulated housing markets of the US and UK.

This paper introduced some of the new forms of gentrification to emerge over the past decade. But it is not just what constitutes gentrification that has evolved over time; it is what happens where and when that varies and changes as well. There is growing interest in the 'geography of gentrification' (Lees 2012) and comparative urban studies. In her recent article on the topic, Lees (2012, p. 164) stated: 'It is now time for gentrification researchers to decolonize the gentrification literature away from Euro-American perspectives and pay much more attention to gentrification in the Global South'. However, we should not ignore a process which is continuing to reshaping 
cities in Europe, North America and the Global North, a point which Lees acknowledges later in her paper. While new approaches, theories and empirical studies from around the world are indeed welcome, we should still continue to examine the similarities and differences concerning how gentrification is implemented, evolves and is experienced within different European contexts. This is particularly true as government policies and gentrification trends continue to evolve in the wake of the on-going economic crisis.

The papers in this special issue primarily focus on Amsterdam, with one case study examining displacement in Istanbul. Studying gentrification in the Netherlands gives us key insights on how gentrification theories 'travel' (see MacLeod 2002; Lees 2012) within a Western or 'Global North' context. In the Netherlands, they 'travel' through a very different politicaleconomic construct with vastly different roles for public private and not-for-profit actors compared to where these theories have originated from (largely New York and London); the Dutch context serves to challenge the universality of these concepts through time and space. While there are no direct international comparisons within this special issue, this greater understanding of Dutch gentrification should serve as a useful comparison to the international literature and help contribute to insights about the 'geography of gentrification'.

\section{OUTLINE OF THE SPECIAL ISSUE}

The papers present in this special issue consist of a cross-section of different theoretical, conceptual and empirical approaches to gentrification research. As such, they provide a good representation of the different strands of research in contemporary gentrification studies, with a spatial focus on the Netherlands, and specifically Amsterdam. The papers in this issue have mostly been drawn from a conference held in Utrecht, the Netherlands, in November 2011 (see www.gentrificationconference.nl). Most of the contributors are Dutch, or work in a Dutch context.

Willem Boterman and Wouter van Gent use longitudinal register data, regression modelling and GIS analysis (rigorous quantitative research not normally seen in gentrification studies) to examine tenure conversion in Amsterdam. They shed light on two major gaps in this literature: the class, ethnic and demographic effects of tenure conversion at a citylevel, and how these effects differ on a spatial level within a city. In their analysis, tenure conversion brings about class, demographic and ethnic changes within a neighbourhood. In some of the post-war neighbourhoods, immigrant groups are able to purchase homes relatively cheaply, while in the inner-city, native-Dutch middle-class households (in many cases with children) find opportunities to buy housing in a very tight and restricted market. They argue that the process of tenure conversion reinforces the distinction between areas which do well, and areas which do not. In the inner-city, this helps to stimulate gentrification, while in more outer or marginal areas, it can have the reverse effect, stimulating downgrading of the housing market.

Carla Huisman examines tenant participation in urban restructuring in Amsterdam. Using a Marxist approach, she views participation as a means to gain legitimacy for urban policies, and argues that this participation is, and ends up being, a false promise for residents of social housing in Amsterdam. The local government and the housing corporations who own the housing being converted pursue this policy in order to make the city more attractive for middle-class households, and provide extra (short-term) income from the sale of units or increased rent from private-market tenants. She found that the choices of the government and housing associations about neighbourhood restructuring were given to tenants as facts, rather than as policy choices for their consideration, and were presented to the tenants as the only alternatives. Her ethnographic study involved 19 months of active fieldwork and involved attending meetings, observing and speaking with different actors in the process. She selected two case-studies, one where the tenants comply and another where they resist. She concludes that this type of participation helps to legitimise displacement, rather than giving tenants an actual voice.

Lia Karsten's paper makes significant contributions to two of the new areas of gentrification research mentioned earlier. Her paper examines the link between family gentrifiers and the 
new types of consumption spaces found in cities. She critiques the gentrification literature which is focused on 'loss' - loss of population, commercial spaces, public space and communities. Karsten has a different view on this process; instead of only seeing loss, she highlights new opportunities for urban spaces, communities and activities to emerge, increasingly being centred on families with children. Her case study is her own neighbourhood, where she raised her children. She describes, in vivid detail, and through a combination of interviews with parents and business owners and her own experiences, the new amenities and consumption spaces which have opened, both catering primarily to families and primarily to children, as the neighbourhood has gone further and further upmarket. She does not find a loss of community, but rather new forms of 'villagey networks' which develop, particularly around public consumption spaces such as streets and parks. She notes that this has the potential to reduce gender and age inequalities. Yet, the paper ends on a more mixed note, observing that the more popular the neighbourhood becomes, the more expensive, and commercialised it will be.

The contribution by Olaf Ernst and Brian Doucet examines how those living through gentrification experience it in a rapidly gentrifying neighbourhood in Amsterdam. They do this by interviewing pub patrons in traditionally working-class cafés. Some of the respondents have lived through several changes to the area: first from a Dutch working-class neighbourhood to a more ethnically-mixed one, and now the current gentrification (which brings not only class but ethnic transformations). An analysis of the interviews reveals mixed views on how their neighbourhood is changing. On the one hand, they welcome the fact that the area is becoming ethnically Dutch once again. Amenities which cater to middle-class tastes, values and customers are more favourably received than those which cater to the ethnic minorities. Divisions between gentrifiers and non-gentrifiers are also not as explicit as is often stated in the literature. While the respondents were generally more optimistic than those in many other studies, this could prove to be a temporary moment in time, as there was a sense that one's pub was impervious to change. Therefore, the temporal nature of these positive experiences must be taken into account when drawing long-term conclusions about gentrification's impact.

Bahar Sakizlioglu's paper contributes to on-going debates on gentrification in the Global South. Specifically, she examines the Tarlabasi neighbourhood in Istanbul, which was selected for state-led urban renewal. She answers questions concerning what it is like to live in a house that is due to be demolished, or in a neighbourhood that has been earmarked for class transformation. Using interviews with inhabitants of the neighbourhood, who include Kurdish migrants, sex-workers, street sellers and recyclers, among others, she gives us considerable insight into what it is like to experience displacement. The paper highlights both the threats and harassment which local residents and business owners face and how the process of waiting can further heighten anxieties among those threatened with displacement.

Justus Uitermark and Tjerk Bosker (2014) examine urban policy and gentrification in Amsterdam over the past 20 years. They focus on what they argue are contradictory policy goals during this time of both simultaneously promoting market forces and owner-occupation in the housing market (which tends to segregate the population along class divisions) and social mixing policies aimed at countering segregation. They argue that a socio-economic divide between the core and peripheral neighbourhoods of Amsterdam is increasing despite significant government investment in the latter, although they also question how much larger this divide would be without such programmes and policies.

Finally, Gary Bridge, a prominent AngloSaxon gentrification scholar based in Bristol, will contribute a critical reflection on the papers presented in this special issue and how they fit within wider academic debates. His international research has focused on the gentrifiers in global cities such as London and Paris, as well as more provincial cities such as Bristol (Bridge 2006). More recently, he has been examining gentrification in the Netherlands and the links between gentrification and social mixing (Bridge et al. 2012). 


\section{Acknowledgements}

The author would like to thank Manuel Aalbers, Michael Doucet, the two anonymous referees as well as the other authors contributing to this special issue. The usual disclaimers apply.

\section{Note}

1. This text is from the English-language summary version of Rotterdam's Urban Vision.

\section{REFERENCES}

Aalbers, M. (2011), The Revanchist Renewal of Yesterday's City of Tomorrow. Antipode. 43, 16961724.

Atkinson, R. \& G. BRIDGe (2005), Gentrification in a Global Context. London: Routledge.

August, M. \& A. Walks (2012), From Social Mix to Political Marginalisation? The Redevelopment of Toronto's Public Housing and the Dilution of Tenant Organisational Power. In: G. BRIDGe, T. Butler, \& L. Lees, eds., Mixed Communities: Gentrification by Stealth, pp. 273-298. Bristol: Policy Press.

Bell, D. (1973), The Coming of Postindustrial Society: A Venture in Social Forecasting. New York: Basic Books.

Boddy, M. (2007), Designer Neighbourhoods: Newbuild Residential Development in Nonmetropolitan UK cities - the Case of Bristol. Environment and Planning A 39, pp. 86-105.

Boterman, W. (2013), Dealing with Diversity: Middle-class Family Households and the Issue of 'Black' and 'White' Schools in Amsterdam, Urban Studies 50, pp. 1130-1147.

Boterman, W., \& W. Van Gent (2014), Housing Liberalization and Gentrification: The Social Effects of Tenure Conversion in Amsterdam. Tijdschrift voor Economische en Sociale Geografie 105, pp. 140-160.

BRIDGE, G. (2001), Estate Agents as Interpreters of Economic and Cultural Capital: The Gentrification Premium in the Sydney Housing Market. International Journal of Urban and Regional Research 25, pp. 87-101.

BRIDGE, G. (2006), It's Not Just a Question of Taste: Gentrification, the Neighbourhood, and Cultural Capital. Environment and Planning A 38, pp. 19651978.

Bridge, G. (2014), Afterword: The Times and Spaces of Gentrification. Tijdschrift voor Economische en Sociale Geografie 105, pp. 231-236.
Bridge, G., T. Butler. \& L. Lees, eds. (2012), Mixed Communities: Gentrification by Stealth. Bristol: Policy Press.

Bridge, G. \& R. Dowling (2001), Microgeographies or Retailing and Gentrification. Australian Geographer 32, pp. 93-107.

Butler, T. (2003), Living in a Bubble: Gentrification and Its 'Others' in North London. Urban Studies 40, pp. 2469-2486.

Butler, T. \& L. Lees (2006), Super-gentrification in Barnsbury, London: Globalization and Gentrifying Global Elites at the Neighbourhood Level. Transactions of the Institute of British Geographers 31, pp. $467-487$.

Buzar, S., R. Hall \& P. Ogden (2007), Beyond Gentrification: The Demographic Reurbanisation of Bologna. Environment and Planning A 39, pp. 64-85.

Clark, E. (2005), The Order and Simplicity of Gentrification. In: R. Atkinson \& G. BRIDGe, eds, Gentrification in a Global Context, pp. 256-264. London: Routledge.

Caulfield, J. (1994), City Form and Everyday Life, Toronto's Gentrification and Critical Social Practices. Toronto: University of Toronto Press.

Cheshire, P. (2012), Why Do Birds of a Feather Flock Together? In: G. BRIDGe, T. Butler \& L. LEes, eds., Mixed Communities: Gentrification by Stealth? pp. 17-24. Bristol: The Policy Press.

DARLING, E. (2005), The City in the Country: Wilderness Gentrification and the Rent-gap. Environment and Planning A 37, pp. 1015-1032.

Deener, A. (2007), Commerce as the Structure and Symbol of Neighborhood Life: Reshaping the Meaning of Community in Venice, California. City and community 6, pp. 291-314.

Davidson, M. \& L. Lees (2005), New-build 'Gentrification' and London's Riverside Renaissance. Environment and Planning A, 37, pp. 11651190.

Doucet, B. (2013), Variations of the Entrepreneurial City: Goals, Roles Visions in Rotterdam's Kop van Zuid and the Glasgow Harbour megaprojects. International Journal of Urban and Regional Research. 37, pp. 2035-2051.

Doucet, B. (2009), Living through Gentrification: Subjective Experiences of Local, Non-gentrifying Residents in Leith, Edinburgh. Journal of Housing and the Built Environment 24, pp. 299-315.

Doucet, B., R. Van Kempen \& J. VAN Weesep (2011), 'We're a Rich City with Poor People': Municipal Strategies of New-build Gentrification in 
Rotterdam and Glasgow. Environment and Planning A 43, pp. 1438-1454.

Ernst, O. \& B. Doucet (2014), A Window on the (Changing), Neighbourhood: The Role of Pubs in the Contested Spaces of Gentrification, Tijdschrift voor Economische en Sociale Geografie 105, pp. 189-205.

Fainstein, S. (2008), Megaprojects in London, New York and Amsterdam. International Journal of Urban and Regional Research. 32, pp. 768-785.

Freeman, L. (2006), There Goes the Hood: Views of Gentrification from the Ground Up. Philadelphia, PA: Temple University Press.

Friedmann, J. (1986), The World City Hypothesis. Development and Change 17, pp. 69-83.

GaWC (2010), The World According to GaWC 2010.Globalization and World Cities Research Network. Available at <http://www.lboro.ac.uk/gawc/ world2010t.html>. Accessed on 16 November 2013 .

GLAss, R. (1964), Introduction: Aspects of Change. In: R. Glass, ed., London: Aspects of Change. London: MacGibbon and Kee.

GLynn, S. (2008), Soft-selling Gentrification? Urban Research and Practice. 1, pp. 164-180.

GLynN, S. (2012), 'Regeneration' in Interesting Times: A Story of Privatisation and Gentrification in a Peripheral Scottish City. In: G. Bridge, T. Butler \& L. Lees, eds., Mixed Communities: Gentrification by Stealth, pp. 185-208. Bristol: Policy Press.

Gopnik, A (2006), Through the Children's Gate: A Home in New York. New York: Knopf.

Gотнам, K.F. (2005), Tourism Gentrification: The Case of New Orleans' Vieux Carre (French Quarter). Urban Studies. 42, pp. 1099-1121.

Hackworth, J. \& N. Smith, N. (2001), The Changing State of Gentrification. Tijdschrift voor Economische en Sociale Geografie 92, pp. 464-477.

He, S. (2010), New-build Gentrification in Central Shanghai: Demographic Changes and Socioeconomic Implications. Population Space and Place. 16, pp. 345-361.

Huisman, C. (2014), Displacement through Participation. Tijdschrift voor Economishce en Sociale Geografie 105, pp. 161-174.

IMRIE, R. \& M. RACo, eds. (2003), Urban Renaissance? New Labour, Community and Urban Policy. Bristol: Policy Press.

Islam, T. (2005), Outside the Core: Gentrification in Istanbul. In: R. AtKinson \& G. BRIDGe, eds., Gentrification in a Global Context, pp. 121-136. Abingdon: Routledge.
Karsten, L. (2014), From Yuppies to Yupps: Family Gentrifiers Consuming Spaces and Re-inventing Cities, Tijdschrift voor Economische en Sociale Geografie 105, pp. 175-188.

Karsten, L. (2003), Family Gentrifiers: Challenging the City as a Place Simultaneously to Build a Career and to Raise Children. Urban Studies 40, pp. 25732584.

LeEs, L. (2000), A Reappraisal of Gentrification: Towards a 'Geography of Gentrification'. Progress in human geography 24, pp. 389-408.

Lees, L (2003a) Super-gentrification: The Case of Brooklyn Heights, New York City. Urban Studies 40, pp. 2487-2509.

LeEs, L (2003b) Visions of 'Urban Renaissance': The Urban Task Force Report and the Urban White Paper. In: R. ImRIE \& M. RAco, (eds.), Urban Renaissance? New Labour, community and urban policy, pp. 61-82. Bristol: The Policy Press.

LeEs, L. (2012), The Geography of Gentrification: Thinking Through Comparative Urbanism. Progress in Human Geography 36, pp. 155-171.

LeEs, L. \& D. Ley (2008), Introduction to Special Issue on Gentrification and Public Policy. Urban Studies 45, pp. 2379-2384.

Lees, L.,T. Slater \& E. Wyly (2008), Gentrification. New York: Routledge.

Ley, D. (1988), Social Upgrading in Six Canadian Inner Cities. The Canadian Geographe. 32, pp. 31-45.

Ley, D. (1996), The New Middle Class and the Remaking of the Central City. Oxford: Oxford University Press.

LEy, D. (2003), Artists, Aestheticisation and the Field of Gentrification. Urban Studies 40, pp. 2527-2542.

MacLeod, G. (2002), From Urban Entrepreneurialism to a 'Revanchist City?' On the Spatial Injustices of Glasgow's Renaissance. International Journal of Urban and Regional Research. 34, pp. 602-624.

Musterd, S. \& J. van der Ven (1991), Gentrification and Residential Revitalization in Amsterdam. In: J. VAN WeEseP \& S. Musterd, eds., Urban Housing for the Better-off: Gentrification in Europe, pp. 89-97. Utrecht: Stedelijke Netwerken.

Osman, S. (2011), The Invention of Brownstone Brooklyn: Gentrification and the Search for Authenticity in Post-war New York. Oxford: Oxford University Press. Paton, K. (2012), Not the Only Power in Town? Challenging Binaries and Brining the Working Class into Gentrification Research. In: G. BRIDGE, T. Butler \& L. Lees, eds., Mixed Communities: Gentrification by Stealth, pp. 252-272. Bristol: Policy Press. 
Phillips, M. (1993), Rural Gentrification and the Processes of Class Colonisation, Journal of Rural Studies 9, pp. 123-140.

Phillips, M. (2004), Other Geographies of Gentrification. Progress in Human Geography 28, pp. 5-30.

Posthumus, H. (2013), Displacement Myths: The Real and Presumed Effects of Forced Relocations Resulting from Urban Renewal (PhD dissertation, Utrecht).

Rossi, P. (1980), Why Families Move. Beverly Hills, CA: Sage Publications.

RotTerdam (2007), Stadsvisie Rotterdam (Rotterdam Urban Vision). Rotterdam: Dienst Stedenbouw en Volkshuisvesting, Ontwikkelingsbedrijf Rotterdam (Housing and urban development, Rotterdam development corporation).

SAKizlioglu, B. (2014), Inserting Temporality into the Analysis of Displacement: Living Under the Threat of Displacement. Tijdschrift voor Economische en Sociale Geografie 105, pp. 206-220.

Slater, T. (2006), Bovenkant formulier The Eviction of Critical Perspectives from Gentrification Research. International Journal of Urban and Regional Research 30, pp. 737-758.

Smith, D. (2005), 'Studentification': The Gentrification Factory? In: R. Atkinson \& G. BRidge, eds., Gentrification in a Global Context, pp. 72-89. London: Routledge.

Smith, D. \& L. Holt (2007), Studentification and 'Apprentice' Gentrification within Britain's Provincial Towns and Cities: Extending the Meaning of Gentrification. Environment and Planning A 39, pp. 142-161.

Smith, D. \& M. Phillips (2001), Socio-cultural Representations of Greentrified Pennine Rurality. Journal of Rural Studies 17, pp. 457-469.

Smith, N. (1996), The New Urban Frontier: Gentrification and the Revanchist City. New York: Routledge.

Smith, N. (2002), New Globalism, New Urbanism: Gentrification as a Global Urban Strategy. Antipode 34, pp. 427-450.

Sullivan, D. M. \& S. Shaw (2011), Retail Gentrification and Race: The Case of Alberta Street in Portland, Oregon. Urban Affairs Review 47, pp. 413432.

Teernstra A. \& W. Van Gent, (2012), Puzzling Patterns in Neighbourhood Change: Upgrading and Downgrading in Highly Regulated Urban Housing Markets. Urban Geography 33, pp. 91-119. Uitermark, J. (2009), An in memoriam for the Just City of Amsterdam. City 13, pp. 347-361.

Uitermark, J. \& T. Bosker (2014), Wither the 'Undivided City'? An Assessment of Statesponsored Gentrification in Amsterdam. Tijdschrift voor Economishce en Sociale Geografie 105, pp. 221230.

Uitermark, J., J.W. Duyvendak \& R. Kleinhans (2007), Gentrification as a Governmental Strategy: Social Control and Social Cohesion in Hoogvliet, Rotterdam. Environment and Planning $A$ 39, pp. 125-142.

VAn Gent, W. (2013), Neoliberalization, Housing Institutions and Variegated Gentrification: How the 'Third Wave' Broke in Amsterdam. International Journal of Urban and Regional Research 37, pp. 503-522.

Van Kempen, R. and J. Van Weesep (1994), Gentrification and the Urban Poor: Urban Restructuring and Housing Policy in Utrecht. Urban Studies 31, pp. 1043-1056.

VAN WeESEP, J (1994), Gentrification as a Research Frontier. Progress in Human Geography 18, pp. 74-83.

VAN WeEsep, J. \& M. Wiegersma (1991), Gentrification in the Netherlands: Behind the Scenes. In: J. Van Weesep \& S. Musterd, eds., Urban Housing for the Better-off: Gentrification in Europe, pp. 98-111. Utrecht: Stedelijke Netwerken.

Visser, G. \& N. Kotze (2008), The State and Newbuild Gentrification in Central Cape Town, South Africa. Urban Studies 45, pp. 2565-2593.

WACQUANT, L. (2008), Relocating Gentrification: The Working Class, Science and the State in Recent Urban Research. International Journal of Urban and Regional Research 32, pp. 198-205.

WAtт, P. (2008), The Only Class in Town? Gentrification and the Middle-class Colonization of the City and the Urban Imagination. International Journal of Urban and Regional Research 32, pp. 206-211.

Zukin, S. (2008), Consuming Authenticity, from Outposts of Difference to Means of Exclusion. Cultural Studies 22, pp. 724-748.

Zukin, S. (2009), New Retail Capital and Neighborhood Change: Boutiques and Gentrification in New York City. City and community 8, pp. 47-64. 